\title{
ANALISIS YURIDIS PENGATURAN IDEAL PENINJAUAN KEMBALI PERKARA PIDANA PASCA PUTUSAN MAHKAMAH KONSTITUSI NOMOR 34/PUU-XI/2013
}

\author{
Agung Barok Pratama \\ Email: agung.avicena@gmail.com \\ Mahasiswa Magister Ilmu Hukum Universitas Sebelas Maret Surakarta \\ Aminah \\ Email: aminah.8787@gmail.com \\ Moh. Jamin \\ Email: jamin_mh@yahoo.com \\ Dosen Fakultas Hukum Universitas Sebelas Maret Surakarta
}

\begin{abstract}
This article discusses the ideal setting reconsideration after the Constitutional Court decision No. 34/PUU-XII/2013. This research is legal (judicial) normative, namely by reviewing library materials (literature study). Therefore, the data used in this research is secondary data, which includes the primary legal materials, secondary, and tertiary. The results of this study showed that realizing an ideal regulatory application for review should be conducted, first, the MA should retract SEMA 72014 it is necessary to avoid confusion law enforcement officials and people seeking justice so as to interfere with the judicial system. If want to make additional rules to facilitate the course of justice, the MA should be poured in the form of PERMA. Second, by accelerating the process of $P K$ and execution. Thirdly, provision $P K$ in the future submission must be adapted to the Constitutional Court decision No. 34/PUU-X/2013. That way the material truth and justice will actually be realized.
\end{abstract}

Keywords: Judicial Review; Justice; Rule of Law; Supreme Court Decisions.

\begin{abstract}
Abstrak
Artikel ini meneliti tentang pengaturan ideal peninjauan kembali pasca putusan Mahkamah Konstitusi No. 34/PUU-XII/2013.Penelitian ini merupakan penelitian hukum (yuridis) normatif, yaitu dengan mengkaji bahan-bahan pustaka (studi kepustakaan). Karena itu, data yang digunakan dalam penelitian ini adalah data skunder, yang mencakup bahan hukum primer, skunder, dan tersier. Hasil Penelitian ini menunjukan bahwa, demi menwujudkan suatu peraturan yang ideal permohonan peninjauan kembali maka perlu dilakukan, pertama, MA harus menarik kembali SEMA No.7 Tahun 2014 hal ini ini diperlukan agar tidak terjadi kebingungan aparat penegak hokum dan masyarakat pencari keadilan sehingga dapat mengganggu sistem peradilan. Kedua, dengan mempercepat proses PK dan eksekusinya. Ketiga, ketentuan pengajuan PK kedepanya harus disesuaikan dengan putusan MK No. 34/PUU-XI/2013. Dengan begitu keadilan dan kebenaran materiil akan benar-benar dapat diwujudkan.
\end{abstract}

Kata kunci: Peninjauan Kembali, Keadilan, Kepastian Hukum, Putusan Mahkamah Agung 


\section{A. Pendahuluan}

Peninjauan Kembali yang disingkat PK adalah suatu upaya hukum yang dipakai oleh terpidana untuk memperoleh penarikan kembali atau perubahan terhadap putusan hakim yang pada umumnya tidak dapat diganggu gugat lagi (Soedirjo, 1983: 11). Dalam sistem tata cara peradilan di Indonesia, putusan yang telah memperoleh kekuatan hukum tetap, tidak dapat dibuka lagi (UU No. 1/ 1946: 76).Ne bis in idem yang berarti "tidak dua kali dalam hal yang sama", dengan demikian ada kepastian hukum.

Peninjauan kembali menurut Sudikno Mertokusumo, merupakan upaya hukum terhadap putusan tingkat akhir dan putusan yang dijatuhkan di luar hadir tergugat (verstek), dan yang tidak lagi terbuka kemungkinan untuk mengajukan perlawanan (Sudikno, 1994: 92).

Peninjauan kembali merupakan upaya hukum luar biasa yang dapat dilakukan setelah putusan memperoleh kekuatan hukum tetap. Dibentuknya lembaga PK dalam perkara pidana berpijak pada pasal 263 ayat (1) KUHAP yang menyatakan5 :

"Terhadap putusan pengadilan yang telah mempunyai kekuatan hukum tetap, kecuali putusan bebas atau lepas dari tuntutan hukum, terpidana atau ahli warisnya dapat mengajukan permintaan peninjauan kembali kepada Mahkamah Agung”.

Berdasarkan Kitab Undang-Undang Hukum Acara Pidana (KUHAP) Bab XVIII UU Nomor 8 Tahun 1981, PK merupakan salah satu upaya hukum luar biasa dalam sistem peradilan di Indonesia (Soedirjo, 1983: 11). Upaya hukum luar biasa merupakan pengecualian dari upaya hukum biasa yaitu persidangan pada Pengadilan Negeri, sidang banding pada Pengadilan Tinggi, dan kasasi pada Mahkamah Agung.
Ketentuan PK diatur dalam Peraturan Mahkamah Agung Nomor 1 Tahun 1969 (Perma, 1969: 1) tentang Peninjauan Kembali Putusan Pengadilan Yang Telah Memperoleh Kekuatan Hukum Tetap, sedang aturan PK sendiri telah diatur dalam KUHAP pasal 263 sampai dengan pasal 269.

Pasal 263 (1) KUHAP menentukan bahwa PK boleh diajukan oleh terpidana atau ahli warisnya (Adami, 2011: 4). Diperbolehkanya pengajuan PK terhadap putusan pengadilan yang telah memperoleh kekuatan hukum tetap, bukan tanpa syarat atau kondisi. Di dalam pasal 263 ayat (2) mesyaratkan, PK dapat diajukan terhadap putusan kasasi Mahkamah Agung apabila pada putusan sebelumnya diketahui terdapat kesalahan atau kekhilafan hakim dalam memutus perkara ataupun terdapat bukti baru yang belum pernah diungkapkan dalam persidangan. Demi adanya kepastian hukum dalam pengajuan PK maka, pada pasal 268 ayat (3) KUHAP menyatakan, bahwasanya pengajuan $\mathrm{PK}$ atas suatu putusan hanya dapat dilakukan satu kali saja.

Perkembangan kenegaraan menunjukkan bahwa tiada satupun negara yang tidak memunyai konstitusi. Inggris sekalipun yang sering dijadikan sebagai contoh negara tanpa konstitusi pada prinsipnya mengakui dan mempraktikkan ketatanegaraannya dengan konstitusi, meskipun bentuknya tidak sebagaimana Undang-Undang Dasar pada umumnya yang tertulis (Muhtadi, 2015:316).

Perkembangan selanjutnya, Majelis Hakim Mahkamah Konstitusi menyatakan bahwa Pasal 268 ayat (3) Undang-Undang Nomor 8 Tahun 1981 tentang Hukum Acara Pidana (KUHAP), bertentangan dengan Undang-Undang Dasar 1945 karena membatasi PK oleh terdakwa hanya sekali. Namun, hilangnya kepastian hukum akibat berulangnya PK, membuat Mahkamah Agung memutuskan untuk menentukan sikap yang tegas. Mahkamah Agung sebagai salah satu 
lembaga peradilan tertinggi di Indonesia menentukan sikapnya dengan mengeluarkan SEMANo. 7 Tahun 2014 dengan berlandaskan pada Pasal 24 ayat (2) UU No. 48 Tahun 2009 tentang Kekuasaan Kehakiman, yang berbunyi "Terhadap putusan peninjauan kembali tidak dapat dilakukan peninjauan kembali", dan Pasal 66 ayat (1) UU Nomor 3 Tahun 2009 tentang Mahkamah Agung, yang berbunyi "Permohonan peninjauan kembali dapat diajukan hanya 1 (satu) kali”.

Namun peraturan yang dibentuk Mahkamah Agung tentu tidak dapat disamakan dengan peraturan yang dibentuk lembaga legislatif. Dilihat dari bentuknya SEMA tidak memiliki bentuk formal yang serupa dengan peraturan perundang-undangan pada umumnya.Umumnya Peraturan PerundangUndangan memiliki bagian-bagian pembentuk seperti Penamaan, Pembukaan, Batang Tubuh, dan Penutup. (Maria, 1998: 157). Bagianbagian tersebut tidak utuh dijumpai dalam SEMA.Selain itu, kedudukan SEMA dalam hierarki peraturan perundang-undangan di Indonesia belum pernah termaktub secara konkrit dalam tata urutan peraturan-perundangundangan.Dalam Undang-Undang Nomor 12 Tahun 2011 tentang pembentukan peraturan perundang-undangan tidak disebutkan derajat dan hierarki Surat Edaran Mahkamah Agung (SEMA).

Di sisi lain, putusan Mahkamah Konstitusi Nomor 34/XI-PUU/2013 berdampak pada permohonan PK dapat dilakukan lebih dari satu kali demi terwujudnya keadilan yang seluasluasnya. Pada perkembanannya Mahkamah Agung merespon Putusan Mahkamah Konstitusi dengan menerbitkan SEMA Nomor 7 Tahun 2014 yang menegaskan kembali bahwa aturan PK perkara pidana hanya dapat dilakukan satu kali. Benturan pengaturan PK akan menciptakan ketidakpastian hukum dan dikhawatirkan akan timbul keragu-raguan hakim dalam menerapkan norma tentang PK. Maka menarik untuk dibahas dalam sebuah penelitian mengenai pengaturan ideal PK pasca terbitnya SEMA No. 7 Tahun 2014.

Berdasarkan latar belakang tersebut, maka permasalahan yang akan dikaji oleh penulis adalah bagaimanakah pengaturan ideal Peninjauan Kembali Perkara Pidana pasca Putusan Mahkamah Konstitusi No. 34/ XI-PUU/ 2013.

\section{B. Metode Penelitian}

Penelitian dalam artikel ini termasuk dalam jenis penelitian doktrinal. Penelitian hukum doktrinal atau jenis penelitian normatif adalah penelitian hukum yang meletakan hukum sebagai sebuah bangunan sistem norma. Sistem norma yang dimaksud adalah mengenai asas-asas, norma, kaidah dari peraturan perundang-undangan, putusan pengadilan, perjanjian serta doktrin atau ajaran (Mukti, 2010: 34).

Ditinjau dari bentuknya, artikel hukum ini menggunakan bentuk penelitian preskriptif yang mana bentuk penelitian ini bertujuan untuk mendapatkan saran-saran mengenai apa yang harus dilakukan utuk mengatasi suatu masalah hukum tertentu.

Pendekatan penelitian yang digunakan antara lain; pendekatan undang-undang (statue approach), pendekatan kasus (case approach) dan pendekatan konseptual (conseptual approach) (Peter, 2005: 133).

Sumber bahan hukum dalam artikel ini adalah; 1) Bahan Hukum Primer. Bahan-bahan hukum primer adalah semua aturan hukum yang dibentuk dan/atau dibuat secara resmi oleh suatu lembaga negara, dan/atau badanbadan pemerintahan, yang demi tegaknya akan diupayakan berdasarkan daya paksa yang dilakukan secara resmi pula oleh aparat negara. Masih termasuk ke dalam pengertian bahan hukum primer ini adalah juga seluruh amar putusan badan yudisial (Peter, 2005: 135). 2) Bahan Hukum Sekunder. Sebagai 
bahan hukum sekunder yang terutama adalah buku-buku hukum termasuk skripsi, tesis, dan disertasi hukum dan jurnal-jurnal hukum. Disamping itu juga, kamus-kamus hukum, dan komentar-komentar atau putusan pengadilan.

Teknik pengumpulan data yang digunakan bahan hukum; 1) Studi Kepustakaan (Library Research). Teknik analisis data dalam artikel ini menggunakan metode deduktif. Metode ini berpangkal dari pengajuan premis mayor kemudian diajukan premis minor atau akan ditarik kesimpulan dari suatu permasalahan yang umum terhadap permasalahan khusus yang dihadapi.

\section{Hasil Penelitian dan Pembahasan}

1. Peninjauan Kembali Pasca Putusan Mahkamah Konstitusi No. 34/PUUXI/2013

Dalam konteks hukum acara pidana, ketentuan batas pengajuan PK telah diatur dalam Undang-Undang No. 1 Tahun 1981 tentang Kitab Undang-Undang Hukum Acara Pidana (KUHAP). Ketentuan mengenai PK ditampung di dalam Pasal 263-269. Sedangkan ketentuan yang mengatur batasan pengajuan PK terdapat pada Pasal 268 ayat (3) bahwa "permintaan peninjauan kembali atas suatu putusan hanya dapat dilakukan satu kali saja". Ketentuan ini sama seperti yang ditentukan dalam Pasal 24 ayat (2) UU No. 48 Tahun 2009 dan Pasal 66 ayat (1) Undang-Undang Nomor 14 Tahun 1985 tentang Mahkamah Agung sebagaimana telah diubah dengan Undang Undang Nomor 5 Tahun 2004 yang telah diuraikan di atas. Oleh karena itu menurut KUHAP batas pengajuan PK hanya dapat dilakukan satu kali oleh terpidana atau ahli warisnya.

Dalam perkembanganya Majelis Hakim Mahkamah Konstitusi dalam putusannya No. 34/PUU-XI/2013 menyatakan bahwa Pasal 268 ayat (3)
Undang-Undang Nomor 8 Tahun 1981 tentang Hukum Acara Pidana (KUHAP), tidak mempunyai kekuatan hokum mengikat dan bertentangan dengan Undang-Undang Dasar 1945. Putusan ini dibuat dalam rapat Permusyawaratan Hakim Konstitusi Pada tanggal 22 juli 2013 dikeluarkan dalam siding pleno Mahkamah Konstitusi pada tanggal 6 Maret 2014.

Latar belakang dilakukannya uji materi terhada pasal 268 Ayat (3) KUHAP adalah permohonan uji materi yang diajukan oleh Antasari Azhar, yang telah divonis selama 18 tahun penjara akibat didakwa membunuh direktur PT. Rajawali Putra Banjaran, sebagaimana diputuskan di tingkat pertama oleh Pengadilan Negeri Jakarta Selatan No. 1532/ Pid.B/ 200 9/ PN. Jkt.Sel tanggal 11 Februari 2010 dan telah mempunyai kekuatan hukum tetap (inkracht van gewijsde) dengan putusan Mahkamah Agung (MA) No. 1429K/ Pid/ 2010 tanggal 21 September 2010 (Shanty, 2014: 01).

Terdapat beberapa model putusan MK, diantaranya adalah model putusan yang secara hukum membatalkan dan menyatakan tidak berlaku (legally null and void), konstitusional bersyarat (conditionally constitutional), inkonstitutional bersarat, pemberlakuannya ditunda (limited constitutional), merumuskan norma baru, langsung dapat dieksekusi (self implementing) dan tidak langsung dapat dieksekusi (non-self implementing) (Syukri, 2003: 8-26).

Apabila melihat petitum para pemohon tersebut dapat disimpulkan bahwa permohonan tersebut dengan model putusan konstitusional bersyarat (conditioanally constitutional) dengan menitik beratkan pada hak untuk mendapat 
manfaat dari ilmu pengetahuan dan teknologi, sebagaimana dimaksud pada pasal 28C ayat (1) UUD 1945. Sehingga berbunyi:

"Permintaan Peninjauan Kembali atas suatu putusan hanya dapat dilakukan satu kali saja, kecuali terhadap alasan ditemukannya bukti baru berdasarkan pemanfaatan ilmu pengetahuan dan teknologi dapat diajukan lebih dari sekali”.

Namun dalam Putusan MK tidak memutusnya dengan model putusan bersyarat, sebagaimana permohonan para pemohon. Sehingga amar putusan Mahkamah Konstitusi No. 34/PUUXI/2013 menyatakan:

1. Mengabulkan permohonan para Pemohon:

i. Pasal 268 ayat (3) UndangUndang Nomor 8 Tahun 1981 tentang Hukum Acara Pidana (Lembaran Negara Republik Indonesia Tahun 1981 Nomor 76, Tambahan Lembaran Negara Republik Indonesia Nomor 3209) bertentangan dengan UndangUndang Dasar Negara Republik Indonesia Tahun 1945;

ii. Pasal 268 ayat (3) UndangUndang Nomor 8 Tahun 1981 tentang Hukum Acara Pidana (Lembaran Negara Republik Indonesia Tahun 1981 Nomor 76, Tambahan Lembaran Negara Republik Indonesia Nomor 3209) tidak mempunyai kekuatan hukum mengikat;

2. Memerintahkan pemuatan putusan ini dalam Berita Negara Republik Indonesia sebagaimana mestinya;

Berdasarkan Amar Putusan Mahkamah Konstitusi No. 34/PUU-XI/2013 tersebut jika dilihat dari model-model putusan MK maka dalam putusanya MK menggunakan model putusan yang secara hukum membatalkan dan menyatakan tidak berlaku (legally null and void). Dalam Putusan MK No. 34/PUU-XI/2013 amar putusannya membatalkan dan menyatakan tidak berlaku pasal 268 ayat (3) KUHAP karena bertentangan dengan UndangUndang Dasar 1945. Dengan model putusan ini MK menyatakan bahwa suatu Undang-Undang yang diuji dan bertentangan dengan Undang-Undang Dasar 1945 baik seluruhnya maupun sebagian, sehingga Undang-Undang yang dinyatakan batal tersebut dinyatakan tidak memiliki kekuatan hukum mengikat lagi sejak diucapkan dalam sidang pleno yang terbuka untuk umum (Syukri, 2003: 8).

Dibatalkannya Pasal 268 ayat (3) KUHAP yang membatasi pengajuan PK lewat Putusan MK No. 34/PUU-XI/2013, maka ketentuan pasal tersebut tidak dapat lagi digunakan sebagai dasar hukum. Jika ada pejabat negara atau warga negara yang masih tetap menggunakan ketentuan dalam pasal tersebut atau Undang-Undang yang telah dinyatakan tidak mengikat itu berarti tindakannya tidak memiliki dasar hukum. Oleh sebab itu, jika upaya hukum PK masih dibatasi satu kali maka perbuatan tersebut termasuk dalam perbuatan melawan hukum dan demi hukum batal sejak awal.

2. Analisis Terbitnya Surat Edaran Mahkamah Agung Nomor 7 Tahun 2014

Putusan MK bersifat final and binding (Undang-Undang, 2011: 8), sehingga putusan MK langsung memperoleh kekuatan hukum tetap sejak diucapkan dan tidak ada upaya hukum yang dapat ditempuh.Selain itu putusan MK juga mengikat bukan hanya bagi para pihak 
yang berperkara namun juga seluruh warga negara.

Sangat penting bagi MA juga untuk segera menyusun peraturan MA untuk menjabarkan dari putusan MK No. 34/PUU-XI/2013 melalui peraturan operasional mengenai kriteria dan syarat pengajuan PK yang mencerminkan dimensi kepastian hukum, keadilan dan kemanfaatan.

Sebagai salah satupemegang kekuasaan kehakiman MA mempunyai kewenangan dalam membuat suatu peraturan (regeling). Membuat peraturan sebagai pelengkap untuk mengisi kekurangan atau kekosongan hukum yang diperlukan bagi kelancaran jalannya peradilan dan mengatur sendiri administrasinya baik mengenai administrasi peradilan maupun administrasi umum.

Mengacu kepada Undang-undang Nomor 12 Tahun 2011 tentang Pembentukan Peraturan Perundangundangan. Dalam Pasal 8 ayat (1) dan (2), pada intinya, menyatakan bahwa peraturan, yang salah satunya, dikeluarkan oleh Mahkamah Agung diakui keberadaannya dan memiliki hukum mengikat selama diperintahkan oleh peraturan perundangundangan yang lebih tinggi atau dibentuk berdasarkan kewenangan. Dalam hal ini fungsi pengaturan atau "regelen" merupakan kewenangan Mahkamah Agung yang didasari oleh ketentuan Pasal 79 Undang-Undang Nomor 14 Tahun 1985 sebagaimana telah diubah dan ditambah oleh Undang-Undang Nomor 5 tahun 2004 dan Undang-Undang Nomor 3 Tahun 2009 yang berbunyi:

Mahkamah Agung dapat mengatur lebih lanjut hal-hal yang diperlukan bagi kelancaran penyelenggaraan peradilan apabila terdapat hal-hal yang belum cukup diatur dalam Undang-Undang.
Penjelasan Pasal 79 UU No. 14/1985 jo. UU 5/2004 jo. UU 3/2009 tentang Mahkamah Agung, Berbunyi:

Apabila dalam jalannya peradilan terdapat kekurangan atau kekosongan hukum dalam suatu hal, Mahkamah Agung berwenang membuat peraturan sebagai pelengkap untuk mengisi kekurangan atau kekosongan tadi. Dengan Undangundang ini Mahkamah Agung berwenang menentukan pengaturan tentang cara penyelesaian suatu soal yang belum atau tidak diatur dalam Undang-undang ini.

Dalam hal ini peraturan yang dikeluarkan oleh Mahkamah Agung dibedakan dengan peraturan yang disusun oleh pembentuk Undangundang.Penyelenggaraan peradilan yang dimaksudkan Undang-undang ini hanya merupakan bagian dari hukum acara secara keseluruhan. Dengan demikian Mahkamah Agung tidak akan mencampuri dan melampaui pengaturan tentang hak dan kewajiban warga negara pada umumnya dan tidak pula mengatur sifat, kekuatan, alat pembuktian serta penilaiannya atau- pun pembagian beban pembuktian.

Permasalahan yang timbul dari aturan ini adalah tidak dijelaskannya bentuk peraturan yang dapat dikeluarkan oleh Mahkamah Agung, sehingga pada akhirnya ditafsirkan bahwa kewenangan Mahkamah Agung menerbitkan Surat Edaran Mahkamah Agung adalah mengacu kepada pasal ini. Hubungan antara undangundang dan SEMA sendiripun sebenarnya tidak dijelaskan hierarki nya, karena UU 12 Tahun 2011 hanya memasukkan UUD NRI 1945, Tap MPR, UU/Perppu, Peraturan Pemerintah, Peraturan Presiden, Peraturan Pemerintah Daerah Provinsi, dan Peraturan Pemerintah Kabupaten/ Kota. 
Pada Desember 2014, MA mengeluarkan Surat Edaran Mahkamah Agung (SEMA) yang mengatur tentang permohonan peninjauan kembali. Namun, dalam SEMA No. 7 Tahun 2014 tersebut MA justru membatasi peninjauan kembali hanya dapat dilakuan satu kali saja (SEMA, 2014: 7). Isi SEMA No. 7 Tahun 2014 ini bertentangan dengan putusan MK No. 34/PUU-XI/2013 yang amar putusanya mencabut pasal 268 ayat (3) KUHAP sehingga peninjauan kembali tidak lagi dibatasi hanya sekali.

Mengenai Pertimbangan poin satu dan dua SEMA No. 7 Tahun 2014, menyatakan bahwa Putusan MK No. 34/ PUU-XI/2013 hanya menyatakan pasal 268 ayat (3) KUHAP tidak lagi memiliki kekuatan hukum mengikat. Sementara itu, masih ada aturan-aturan lain yang masih menentukan PK hanya satu kali pasal 24 ayat (2) UU No. 3 Tahun 2009 tentang kekuasan Kehakiman dan Pasal 66 ayat (1) UU no. 3 Tahun 2009 tentang MA. MK tidak membatalkan dua pasal lainnya yang juga mengatur tantang upaya hukum PK.

Pada SEMA No. 7 Tahun 2014 dijelaskan bahwa pengaturan upaya hukum PK, selain diatur dalam KUHAP juga diatur dalam Undang-Undang Mahkamah Agung dan Undang-Undang Kekuasaan Kehakiman, yaitu:

a. Undang-Undang Nomor 4 Tahun 2009 tentang Kekuasaan Kehakiman (Lembaran Negara Republik Indonesia Tahun 2009 Nomor 157, Tambahan Lembaran Negara Republik Indonesia Nomor 5076) Pasal 24 ayat (2), berbunyi:

"Terhadap putusan peninjauan kembali tidak dapat dilakukan peninjauan kembali"

b. Undang-Undang Republik Indonesia Nomor 14 Tahun 1985 tentang
Mahkamah Agung sebagaimana telah diubah dengan Undang Undang Nomor 5 Tahun 2004 dan perubahan kedua dengan UndangUndang Nomor 3 Tahun 2009 Pasal 66 ayat (1), berbunyi:

"Permohonan peninjauan kembali dapat diajukan hanya 1 (satu) kali”

Menurut MA, bahwa dengan dinyatakan tidak mempunyai kekuatan hukum mengikat pasal 268 ayat (3) KUHAP oleh Putusan MK No. 34/PUUXI/2013, tidak serta merta menghapus norma hukum yang mengatur PK yang diatur dalam Pasal 24 ayat (2) UndangUnang No. 4 Tahun 2009 dan Pasal 66 ayat (1) Undang-Undang No. 3 Tahun 2009.

Dari jabaran-jabaran di atas, maka dapat kita lihat bahwa terbitnya SEMA No. 7 Tahun 2014 ini didasari atas 3 (dua) hal. Yang pertama, sebagai tanggapan atas putusan Mahkamah Konstitusi (MK) Nomor 34/PUU-XI/2013 tanggal 6 Maret 2014, yang menyatakan ketentuan pasal 268 ayat (3) KUHAP (yang mengatur tentang PK hanya dapat dilakukan 1 kali) bertentangan dengan UUD NRI 1945 dan tidak memiliki kekuatan hukum mengikat, tidak serta merta menghapus pasal-pasal yang juga mengatur PK yaitu dalam Pasal 24 ayat (2) UU No. 3 Tahun 2009 tentang kekuasan Kehakiman dan Pasal 66 ayat (1) UU no. 3 Tahun 2009 tentang Mahkamah Agung. Kedua, sebagai tanggapan atas PK yang diajukan oleh beberapa gembong narkoba yang telah divonis mati, sehingga PK dinilai menghalangi jalannya eksekusi terhadap para gembong narkoba tersebut. Selain itu, dikhawatirkan PK yang dapat dilakukan lebih dari 1 (satu) kali (berulang kali) akan digunakan sebagai instrumen bagi 
terpidana untuk berkali-kali mengajukan PK dengan tujuan menunda eksekusi, atau dengan kata lain, PK berulang kali dapat menunda eksekusi dari pidana yang dijatuhkan kepada terpidana.Ketiga, kehawatiran akan semakin bertambah dan menumpuknya kasus PK yang masuk ke MA.

\section{Pengaturan Ideal Peninjauan Kembali Perkara Pidana Pasca Putusan MK No. 34/PUU-XI/2013}

Putusan MK No. 34/PUU-XI/2013 telah menciptakan adanya pengaturan ganda mengenai pembatasan permohonan PK. Setidaknya masih ada dua undangundang yang mengatur permohonan PK dalam perkara pidana, dimana PK hanya dapat diajukan satu kali saja. Kondisi ini melahirkan ketidakharmonisan norma yang berdampak adanya ketidakpastian hokum itu sendiri.

Dalam teori perundang-undangan, pertentangan antara suatu norma dengan norma hokum lainya dapat diuji dengan dua asas, yaitu asas lex posterior derogate legi periori dan lex superior derogate legi inferior. Menurut asas lex posterior derogate legi priori, dalam hierarki peraturan yang sama maka apabila terjadi polemik maka peraturan yang terbarulah yang digunakan. Sedangkan lex superior derogate legi inferiori menentukan bahwa peraturan yang lebih tinggilah yang dimenangkan. Namun dalam kontek pertentangan Putusan MK dengan UU Mahkamah Agung dan UU Kekuasaan Kehakiman, maka yang digunakan adalah asas res judicata pro veriate habetur yang bermakna "jika putusan hakim bertentangan dengan undang-undang, maka putusan hakim yang dimenangkan". Meski pada umumnya putusan hakim bersifat kasuistis (berlaku hanya untuk para pihak), tetapi putusan hakim untuk pengujian peraturan perundang-undangan bersifat erga omnes, yaitu berlaku tidak hanya bagi para pihak yang memohonkan pengujian undang-undang, tetapi juga bagi seluruh pejabat publik dan komponen masyarakat dari berbagai latar belakang.

Erga omnes sering digunakan dalam hokum untuk menjelaskan terminology kewajiban dan hak terhadap sesama. Sebagai contoh sebuah hak kepemilikan adalah sebuah hak erga omnes, dan karena itu dilaksanakan terhadap siapapun. Putusan MK oleh karena objeknya menyangkut kepentingan umum, maka juga belaku sifat erga omnes. Termasuk putusan yang dijatuhkan MK terkait pengujian suatu undang-undang dimana undang-undang sendiri adalah mengikat secara umum kepada semua warga Negara, maka dengan dengan dinyatakan tidak mengikat, undang-undang tersebut tidak lagi memiliki kekuatan hokum mengikat. Bukan hanya kepada para pihak yang memohonkan kan pengujian undang-undang saja tetapi juga berlaku untuk seluruh warga Negara (Bambang, 2006: 43-44). Dilihat dari sifatnya hakikat perkara yang diadili oleh MK tersebut, maka putusan yang dijatuhkan oleh MK bersifat erga omnes. Putusan MK bersifat erga omnes mengikat secara obligatoir bagi seluruh organ Negara, baik pusat dan daerah serta semua otoritas lainya (Abdul Rasyid, 2006: 55). Dengan demikian putusan MK yang merupakan putusan hakim mengalahkan UU Kekuasaan Kehakiman dan UU Mahkamah Agung.

Putusan MK yang telah mengalahkan undang-undang tersebut seharusnya lebih kuat dari pada SEMA yang hanya mengikat secara internal dan tidak termasuk kategori peraturan perundangundangan atau regeling sebagaiman telah dijelaskan sebelumnya. SEMA merupakan 
bentuk edaran yang dikeluarkan oleh pimpinan MA ke seluruh jajaran peradilan yang berisi bimbingan dalam penyelenggaraan peradilan, yang lebih bersifat administrative. Dilihat dari objek norma, SEMA ditujukan kepada hakim, ketua pengadilan, panitera, ataupun pejabat lainya dalam lingkungan peradilan umum, peradilan agama, peradilan militer, peradilan tata usaha Negara sehingga bersifat sebagai kebijakan yang mengatur ke dalam/ internal.

Dalam ilmu perundang-undangan, dikenal sebuah teori yang dikenalkan oleh Hans Kelsen, yang disebut sebagai Stufenbau Theory, yang artinya bahwa suatu peraturan perundang-undangan yang secara hierarkis dibawah tidak boleh bertentangan dengan peraturan perundangundangan yang secara hierarkis berada di atasnya. Dengan bekaca kepada teori ini, dan melihat secara sifat bahwa SEMA, secarta hierarkis berada dibawah undnagundang yang diubah dengan putusan MK, maka sangat jelas bahwa pada dasaranya, SEMA tidak boleh bertentangan dengan undnag-undang, yang telah diubah dengan putusan MK, atau dengan kata lain, SEMA tidak boleh bertentangan dengan putusan MK.

Walaupun demikian putusan judicial review Nomor 34/PUU-XU/2013 terhadap pasal 268 ayat (3) Undang-undang Nomor 8 Tahun 1981 dinyatakan tidak memiliki hokum tetap tersebut dapat diatasi dengan menggunakan instrument hokum Pasal 24 ayat (2) Undang-undang No. 48 Tahun 2009 tentang Kekuasaan Kehakiman dan Pasal 66 ayat (1) Undang-undang Nomor 3 Tahun 2009 tentang Mahkamah Agung yang sama-sama menyatakan bahwa peninjauan kembali hanya dapat dilakukan satu kalai sebagai dasar untuk menolak atau tidak mengabulkan permohonan
PK pada perkara yang sama, sehingga keadilan dan kepastian hokum tercapai. Hal tersebut dikarenakan dua instrument hokum tersebut gradasinya setingkat yakni Undang-undang yang singkron baik secara vertical maupun horizontal dalam system perundang-undangan, sehingga dengan dasar tersebut MA sekiranya tidak perlu secara eksplisit mengeluarkan SEMA tersebut yang akan menimbulkan permasalahan teoritis dan membingungkan, karena pada dasarnya tidaklah mungkin norma yang lebih rendah dapat mengesampingkan norma yang lebih tinggi (lex superior derogate legi inferior).

Gustav Radbruch seorang filosof hukum dan seorang legal scholar dari Jerman mengajarkan konsep tiga ide unsur dasar hukum. Adapun konsep tersebut oleh berbagai pakar diidentikkan juga sebagai tujuan hukum. Adapun tiga tujuan hukum tersebut adalah kepastian Hukum, kemanfaatan, dan keadilan.

Diantara ketiga nilai dasar terdapat suatu Spannungsverhaltnis (ketegangan), oleh karena di antara ketiga nilai dasar hukum tersebut masing-masing mempunyai tuntutan yang berbeda satu sama lainnya, sehingga ketiganya mempunyai potensi untuk saling bertentangan. Apabila diambil sebagai contoh kepastian hukum maka sebagai nilai ia segera menggeser nilai-nilai keadilan dan kegunaan kesamping. Menurut Radbruch, jika terjadi ketegangan antara nilai-nilai dasar tersebut, kita harus menggunakan dasar atau asas prioritas dimana prioritas pertama selalu jatuh pada nilai keadilan, baru nilai kegunaan ataukemanfaatan dan terakhir kepastian hukum. Ini menunjukkan bahwa Radbruch menempatkan nilai keadilan lebih utama daripada nilai kemanfaatan dan nilai 
kepastian hukum dan menempatkan nilai kepastian hukum dibawah nilai kemanfaatan hukum.

Hal ini mendorong pemikiran bahwa tugas peradilan tidak sekedar menyelenggarakan aktivitas interpretasi, tetapi juga memikul tanggung jawab besar agar ketentuan-ketentuan konstitusi dapat diimplementasikan. Maka, dalam pengaturan permohonan PK penulis memiliki beberapa pendapat yang dapat dijadikan solusi untuk mengatasi polemik PK.

Pertama, MA harus menarik kembali SEMA No.7 Tahun 2014 hal ini ini diperlukan agar tidak terjadi kebingungan aparat penegak hokum dan masyarakat pencari keadilan, sehingga dapat mengganggu sistem peradilan. Kalaupun ini mebuat peraturan tambahan untuk memperlancar jalannya peradilan maka MA semestinya menuangkan dalam bentuk PERMA.

Kedua, dengan mempercepat proses PK dan eksekusinya. Hal ini jika diperlu dituangkan dalam norma undangundang yang mempertegas kembali bahwa meskipun PK boleh dilakukan lebih dari satu kali, tetapi setelah PK pertama, pengajuan PK selanjutnya tidak menghalangi pelaksanaan eksekusi. Hal ini sejalan dengan asas litis finiri opotret yakni setiap perkara harus ada akhirnya. Artinya secara kepastian hokum hal ini diperlukan meski masih teruka runag untuk mendapatkan keadilan setelah eksekusi dilaksanakan.

Ketiga, ketentuan pengajuan PK kedepanya harus disesuaikan dengan putusan MK No. 34/PUU-XI/2013. Dengan merumuskan ulang (reformasi) tentang ketentuan batas pengajuan PK seharusnya tidak hanya didasarkan pada novum yang berkaitan dengan pemanfaatan ilmu pengetahuan dan teknologi, namun juga atas novum yang berbeda dengan novum yang dijadikan dasar pengajuan PK sebelumnya. Dengan begitu keadilan dan kebenaran materiil akan benar-benar dapat diwujudkan.

\section{Simpulan}

Berlakunya Putusan MK No. 34/PUU$\mathrm{XI} / 2013$, makaMK dalam putusannya tersebut secara hukum membatalkan atau menyatakan tidak berlaku Pasal 268 ayat (3) KUHAP. Sehingga permohonan PK yang awalnya hanya dapat dilakukan satu kali setelah keluar Putusan MK No. 34/PUU-XI/2013 permohonan PK dapat dilakukan lebih dari satu kali demi tercapainya keadilan. Dan apabila pengajuan PK tetap 'hanya' disetujui sebanyak satu kali, maka tindakan tersebut melanggar hukum dan atau tidak memiliki dasar hukum.

Terbitnya SEMA No. 7 Tahun 2014 ini didasari atas 3 (dua) hal. Yang pertama, sebagai tanggapan atas putusan Mahkamah Konstitusi (MK) Nomor 34/PUU-XI/2013 tanggal 6 Maret 2014. Kedua, sebagai tanggapan atas PK yang diajukan oleh beberapa gembong narkoba yang telah divonis mati, sehingga PK dinilai menghalangi jalannya eksekusi terhadap para gembong narkoba tersebut. Selain itu, dikhawatirkan PK berulang kali dapat menunda eksekusi dari pidana yang dijatuhkan kepada terpidana. Ketiga, kehawatiran akan semakin bertambah dan menumpuknya kasus PK yang masuk ke MA.

Pengaturan ideal Peninjauan Kembali Perkara Pidana menurut penulis antara lain; 1) MA harus menarik kembali SEMA No.7 Tahun 2014, hal ini ini diperlukan agar tidak terjadi kebingungan aparat penegak hukum dan masyarakat pencari keadilan. 2) Mempercepat proses PK dan eksekusinya, 
yaitu bahwa pengajuan Peninjaun Kembali tidak menghalangi proses eksekusi terdakwa. 3) Ketentuan pengajuan PK kedepannya harus disesuaikan dengan putusan MK No. 34/PUU$\mathrm{XI} / 2013$.

\section{E. Saran}

Perlu segera dilakukan tindak lanjut setelah keluarnya Putusan Mahkamah Konstitusi Nomor 34/PUU-XI/2013, yaitu berupa revisi Undang-Undang Nomor 8 Tahun 1981 tentang Hukum Acara Pidana, khususnya di bagian tentang Peninjauan Kembali Putusan Yang Telah Berkekuatan Hukum Tetap.

Pasca keluarnya Putusan Mahkamah Konstitusi Nomor 34/PUU-XI/2013, diperlukan sinkronisasi ketentuan-ketentuan terkait upaya hukum peninjauan kembali seperti Pasal 24 ayat (2) Undang-Undang 48 Tahun 2009 tentang Kekuasaan Kehakiman dan Pasal 66 ayat (1) Undang-Undang Nomor 3 Tahun 2009 tentang Mahkamah Agung dan ketentuan-ketentuan lainnya yang terkait dengan upaya hukum peninjauan kembali.

Membentuk lembaga/panel yang memiliki kewenangan atau mekanisme untuk membantu majelis hakim Pengadilan Negeri dalam memeriksa berkas atau alsan diajukanya PK sebelum diserahkan ke MA. Lembaga ini dapat dibuat menyatu dengan MA dan dapat terdiri dari hakim, jaksa dan ahli. Hal ini dilakukan untuk mengakomodir putusan MK yang mengatakan pencarian keadilan tidak dapat dibatasi serta untuk memaksimalkan proses pembuktian yang maksimal.

\section{F. Daftar Pustaka}

Abdul Rasyid Thalib. 2006. Wewenang Mahkamah Konstitusi dan Aplikasinya dalam Sistem Ketatanegaraan Republik Indonesia. Bandung: Cipta Aditya Bakti.

Adami Chazawi. 2010. Lembaga Peninjauan Kembali (PK) Perkara Pidana. Jakarta: Sinar Grafika.

Bambang, Sunggono. 2013. Metode Penelitian Hukum, ctk. Keempat belas. Jakarta: PT. Raja Grafindo Persada.

Hans Kalsen. 2010. General Theory of Law and State (Teori Umum tentang Hukumdan Negara). Bandung: Nusa Media.

Mahkamah Agung. 2003. Himpunan Surat Edaran Mahkamah Agung (SEMA) dan Peraturan Mahkamah Agung (PERMA) Republik Indonesia Tahun 1951-2003. Jakarta: Mahkamah Agung.

Muhtadi. 2015. "Politik Hukum Pengawasan Hakim Konstitusi”. Justisia jurnal Ilmu Hukum. Vol. 9 No. 3. Juli-September.

Peter Mahmud Marzuki. 2005. Penelitian Hukum. Jakarta: Kencana Prenada Media Group.

Setiono. 2010. Pemahaman Terhadap Metodologi Penelitian Hukum. Surakarta: Program Studi Ilmu Hukum Universitas Sebelas Maret.

Soedirjo. 2014. Peninjauan Kembali dalam Perkara Pidana (Arti dan Makna). cet.1. Jakarta: CV. Akademika Pressindo.

Syukri Asy'ari, et. All. 2013. Model dan implementasi putusan MK dalam pengujian UU (studi putusantahun 2003-2012). Jakarta: Pusat Penelitian dan Pengkajian Perkara, Pengelolaan Teknologi Informasi dan Komuniaksi Kepaniteraan dan Sekertariat Jendral 